UDC 373.5.016:004.738.5

\author{
Marianna V. Shvardak \\ PhD of Pedagogical Sciences, Associate Professor, \\ Associate Professor at the Department of Pedagogy of Pre-school and Primary Education \\ Mukachevo State University, Mukachevo, Ukraine \\ ORCID ID 0000-0002-9560-9008 \\ mariannasvardak2@gmail.com
}

\title{
APPLICATION OF CLOUD TECHNOLOGIES IN PEDAGOGICAL MANAGEMENT
}

\begin{abstract}
The concept "cloud technology" in the context of pedagogical management has been revealed in the article. It has been found that cloud technologies are relevant in education, are intensively integrated into general secondary education, constitute the basis for the formation of information and educational space of an educational institution, are indispensable during the COVID-19 national quarantine. Considering the cloud environment as an environment of effective pedagogical management, the principles on the basis of which cloud technologies of educational institution management are implemented have been determined. It has been revealed that the use of cloud technologies enables the head of the general secondary education institution to fully realize the main functions and directions of pedagogical management. The main modern processes in the cloud environment have been outlined (digitalization, feedback, collaboration, delegation of powers, crowdsourcing, strategic planning, educational benchmarking, joint planning, management of professional development of teachers, PR-activities of educational institutions, control, monitoring, evaluation, testing online). The powerful capabilities of Google's cloud services in terms of management of teachers and educational institutions in general have been analyzed.

Diagnosis has been carried out to determine the state and level of awareness of the possibilities of implementing effective pedagogical management through cloud services. Principals of general secondary education institutions from two regions of Ukraine were involved. The study was conducted in three stages: before COVID-19 quarantine, during the full lockdown and during the adaptive quarantine. As a result of the diagnosis, we have identified three levels of formation of information and digital competence of the principal of an educational institution in the context of the implementation of cloud technologies in pedagogical management: harmonious, functional and unproductive. It has been found that in the conditions of quarantine restrictions, educational managers accumulated their capabilities to the maximum, mastering the necessary cloud services in a short period of time, which led to a sharp increase in their level of information and digital competence.
\end{abstract}

Keywords: cloud technologies; cloud services; pedagogical management; school principal; teachers; general secondary education institution.

\section{INTRODUCTION}

The problem statement. The strategy for the development of national education in accordance with the laws of Ukraine "On Education", "On Complete General Secondary Education" and other laws and regulations requires improving the quality of management in educational institutions of various types.

In modern conditions, the effective functioning of an educational institution largely depends on the ability of its leadership to carry out operational analysis of the situation, handle it promptly and make optimal management decisions. Time requires changes in the nature of information and communication interaction and connections between the agents of the educational process, the emergence of new requirements to the management of educational institutions and the level of their information and digital competence.

Today, the main criterion in choosing a software product for the implementation of the tasks of pedagogical management is compliance with modern requirements of mobility, ease 
of use, efficiency and effectiveness. Therefore, more and more managers are choosing, in the context of educational institution management, cloud technologies, which today, due to their powerful capabilities, are the headliners in the IT market [1]. Cloud technologies provide Internet users with access to computer resources of the server and the ability to use software as an online service, open new perspectives in the management of educational institutions. In the context of a global pandemic, cloud technologies have proved to be the mainstream of emergency support for the smooth implementation of the educational process. Conditions of quarantine restrictions require reengineering of educational activities. This is done through the implementation of a number of organizational and technological changes aimed at mobilizing all available resources and opportunities. The specifics of pedagogical management change, and the educational process, as an object of management, becomes a "virtual enterprise".

The relevance of this study is due to the pressing social need to apply the most modern methods of information management to meet the requirements of the time, transformational processes and qualitative reforms in the development of society. Concern about the magnitude and impact of the COVID-19 pandemic is growing steadily, forcing educational institutions to take a proactive stance and strategize on how to continue teaching and how to manage it in the times of crisis. The principal, together with the team, must develop and implement a set of measures aimed at the continuous and secure provision of educational services in the context of the implementation of measures to contain the pandemic.

It is clear that the efficiency of an educational institution depends on the implementation of its strategies. However, in practice there is often a barrier between goals and reality. This is because the vast majority of educators do not understand how their current responsibilities and tasks relate to the corporate mission. Modern software products, developed on the basis of cloud technologies, allow each teacher to be aware of all events in the educational institution, monitor their performance indicators and understand their personal contribution to the common goal. A wide range of tasks in the work of general secondary education institutions should be transferred online in order to rationally use time, provide effective communication and management.

Analysis of recent research and publications. After analyzing the scientific and pedagogical literature, we have found out that the use of cloud technologies in the educational process has been to some extent researched in the works of T. L. Arkhipova, N. V. Bakhmat, V. Yu. Bykov, V. Yu. Dubnyczkyi, Yu. Yu. Dyulicheva, T. V. Zaitseva, A. M. Kobylin, S. G. Lytvynova, N. V. Morze, L. M. Medzhytova, Yu. B. Olevs`ka, N. V. Rashevs`ka, L. E. Sokolova, V. A. Temnenko, Yu. V. Tryus, V. M. Franchuk and others. Thus, S.H. Lytvynova investigated the theoretical and methodological foundations of designing a cloudbased learning environment of a general secondary education institution [2].

Specificity of the introduction of cloud services (CS) has been studied by M. M. Alabbadi [3], AlAlaa N. Tashkandi [4], S. Lohr [5], J. Reich, J. Watson, L. Pape, J. Rochelle and others.

The use of Google cloud services in the educational process is revealed in the works of V. O. Bohdan, Yu. G. Nosenko, M. V. Noskova, L. V. Rozhdestvens`ka, L. M. Oliinyk, V. P. Oleksyuk, V. O. Khrypun, M. P. Shyshkina. V. O. Khrypun theoretically substantiated and developed scientific and methodological support for the use of Google cloud services in the management of preschool education [6]. M.V. Noskova substantiated the choice of Google services as a basis for mastering the Internet technology by the principal of a general secondary education institution and systematized possible ways of their use in the educational process [7].

Issues of professional training of managers of the new generation were studied by H. V. Yelnikova, L. M. Kalinina, V. I. Luhovyi, V. E. Lunyachek, V. V. Oliinyk and others. 
Despite the large number of scientific papers, the study of cloud technologies in terms of management of general secondary education is not systemic, which is the reason for a detailed research.

The aim of the article is to study the role and features of the application of cloud technologies by school principals in the process of managing a general secondary education institution.

\section{RESEARCH RESULTS}

The main direction of restructuring of pedagogical management and its radical improvement, adaptation to modern conditions is the active use of cloud technologies, because the ability to work with information becomes one of the necessary components of effective management of educators [8, p.105].

Cloud technologies and a new paradigm of educational institution management have become a modern platform for administrative and managerial activities. Management of an educational institution with the use of cloud technologies involves scientifically based actions of management and teachers, which are aimed at the rational use of time, teachers' and students' physical and economic resources in the educational process.

Cloud technologies provide access of managers and teachers to documents generated by the management process (orders, instructions, announcements, schedules, replacements, reports by years and periods, curricula, programs, guidelines, materials for certification of teachers, corporate photo gallery etc). Also, applications can have their own functionality, which corresponds to their place in the management process and the tasks performed by a particular participant in this process. However, the creation of any application with the best functionality will not allow the introduction of cloud technology in the absence of user knowledge and skills [9]. Knowledge of cloud technologies is a definite advantage for those managers who want to work progressively and are persistently looking for new ways to collaborate with teachers and applicants for education. Without exaggeration, it can be argued that these are precisely the technologies that are designed to offload managers and teachers (to reduce the amount of paper routine, endless meetings and discussions of individual management and administrative issues). And also those that make it possible to remotely plan, implement, coordinate, adjust and control the educational process in case of quarantine.

Cloud technologies are implemented at an educational institution on the managerial level on the basis of the following principles: digitalization (translation of information into digital form); mandatory active participation of managerial, pedagogical and supporting (secretaries) staff; accessibility and openness; transparency of each teacher's activity; mobility; awareness of all participants in the educational process of the daily activities of the institution; interactive engagement; convenience of remote delegation of powers; hierarchy (distribution of rights to use data in cyberspace); collective use of data; joint work in their workplaces; adjustment of projects; coordination and synchronization of staff actions; instant feedback.

Considering cloud environment as an environment of effective educational management, we highlight the main processes that are implemented in it. In particular, these are:

- digitalization - the translation of information into digital form, digital transformation as a requirement of today; electronic document management;

- effective feedback - feedback from users of the virtual space (management, teachers, students, parents), the opportunity to express their views; 
- collaboration - joint activities of two or more participants in the educational process to achieve a common goal; in the process of collaboration they share their knowledge, experience, useful information, learn to reach a consensus in the end;

- online delegation - the process of transferring responsibilities and authorities (for example, from the principal to the teacher or focus group);

- crowdsourcing - attracting human resources to jointly solve certain problems or implement educational projects;

- strategic planning, foresight — systematic forecasting of the development of educational institutions in modern conditions;

- educational benchmarking — the activities of employees aimed at improving educational services;

- joint planning - joint work with colleagues on a specific project (development of regulations, plan, schedule, scenario of the holiday);

- online management of teachers' professional development: intervision intercollegiate training in a group of specialists, approximately equal in status and experience, in order to improve professional skills and efficiency; supervision - providing professional and methodological assistance to a less experienced teacher by a more experienced colleague, which is aimed at working with professional difficulties, analysis of shortcomings and improving the organization of work;

- PR-activity of the educational institution - creating a positive image of the institution and maintaining public feedback;

- control, monitoring, evaluation, testing, questionnaires online, etc.

Today, cloud computing services of the following corporations in the Ukrainianlanguage segment of the Internet are the most popular among educators: Google, Microsoft and IBM. It is these corporations that allow for the rapid introduction of cloud computing technologies into the management process of educational institutions [10]. Powerful tools and innovative functionalities of educational clouds allow modern leaders to use these technologies in organizational and managerial activities as effectively as possible. For the effective work of the principal of an educational institution, it is necessary that all cloud services be of the same type, so that he/she does not have to be torn between many accounts, keep in mind many addresses, logins and passwords. In this study, we will focus on Google software products and outline its role in pedagogical management.

According to V. Hladkova, A. Panchenko and H. Panchenko, Google services help the manager in management and are effective tools for strategic planning, control, analysis of work results, stimulating employees to creative search, innovation at various levels and create an environment for public activity, professional communication, self-realization and selfdevelopment of the manager [11, p. 338].

The main functions and areas of pedagogical management that require priority application of hardware and software of cloud management technologies include the following:

- forecasting and planning;

- making management decisions (orders, directives, recommendations, plans, etc.);

- organization of the implementation of decisions and plans, including bringing the decision (plan) to the performer;

- coordination and regulation of performers' activities;

- ensuring operational, current and final controls;

- accounting for performance, analysis and evaluation of its effectiveness [11, p. 340].

In the management activities of the principal of a secondary education institution, Google services are used for: forecasting and planning (Google Calendar, Gmail, Google Forms), management decision-making (Google Gmail, Google Docs, Google Sheets, Google 
Sites, Google Meet), organization (Google Drive, Gmail), coordination (Google Gmail, Hangouts, Google Docs), regulation (Google Gmail), analysis (Google Forms, Sheets), accounting (Google Drive), communications (Google Chat, Gmail, Hangouts, Google Groups, Google+, Google Sites, Google Forms, YouTube, Blogger, Google Classroom), management of teachers' professional development (Google books, Google Scholar, Google Slides, YouTube, Google Meet, Blogger), PR-activities of the educational institution (Google+, Google Sites, Google Forms, YouTube, Blogger) and more.

In our opinion, cloud storage (Google Drive) is most effective in the context of document management. Now all the necessary information and documentation (orders, instructions, announcements, schedules, etc.) can be stored in a cloud educational environment. And possibility to work together and remotely on the same document makes work much easier. Users can view, edit, and create content offline, and all changes are synced when connected to the network. There is no need to repeatedly send the document being edited. There is one document (Google Docs) in the repository that can be worked on by several people, and this document always has its latest version. As a result, time can be significantly reduced, as each employee will enter data in the section previously assigned to him/her. Thus, together with colleagues, you can develop an online program for the development of educational institutions, curricula, local regulations, teaching materials and more.

The Google Calendar service gives a possibility to schedule an event, as well as create shared calendars to record recurring events, and display these events for units that have access.

After an event is created, the process of inviting relevant teachers is carried out. Corporate mail accounts are used for this purpose. Colleagues receive an automatic notice. Attendance, for example, at the meeting is possible in two ways - face-to-face and online. In the case of face-to-face presence, colleagues confirm the request, their Calendar creates a mark "engaged" during the meeting, and they receive duly reminders about the event. In the case of online participation, colleagues join the meeting using the Hangouts service. Working documents can be created and accessed for processing on Google Drive. Work with documents is carried out using a corporate account, all changes in the documents are recorded by the service.

To analyze the effectiveness of the meeting and monitor problematic issues, the leader creates a questionnaire (Google Forms), colleagues answer questions. The service allows to generate summary data for reporting and further analysis. Colleagues' personal blogs, the leader's blog, an educational institution's or a virtual teacher's room (Google Blogger) are used for reflection by colleagues and coverage of the meeting.

Further planning of activities is carried out during and after the meeting. Events are recorded in the Calendar. Further communication and cooperation is carried out using corporate mail, Hangouts and Drive services.

With Google Calendar, one can schedule events related to the operation of a secondary education institution. For each event, Google Calendar creates two events with notification settings (via SMS, email, or social media). One message contains a reminder that an event will take place at the appointed time, the second at the appointed time will be sent to system users with reference to the event [11, p. 341-342].

One can create "thematic" calendars (calendar with dates of birth of colleagues, calendar of subject weeks, school events). The sharing function of electronic calendars provides new opportunities for collaboration and joint work planning by colleagues. With the help of the calendar, the administration of the institution receives excellent opportunities for internal control, monitoring various aspects of the assigned tasks, in particular, the dates of 
the beginning and completion of their implementation, duration, degree of completion and the like.

The Google Sheets service is effective for control purposes. For example, the summary online table "Schoolchildren attendance" with shared access (teachers and school administration) will allow the teacher in his/her lesson to mark absentees in this service. Thus, the supervisor will be able to control schoolchildren' attendance online.

Approval of teachers' plans and teaching materials by the principal can now also take place online. A teacher creates his/her profile and provides access, if necessary, for monitoring of certain materials by the administration.

Google Chat Team Messenger simplifies the interaction between participants in the educational process and ensures timely completion of tasks. One can use it to send personal messages or communicate with all team members at once. Dedicated virtual rooms for working on long-term projects and message chains allow tracking progress and monitoring tasks.

Cloud services also allow the manager to delegate authority remotely. As a result of delegation, the distribution of work in the management system is carried out. For each employee, the manager in a virtual environment assigns a specific job and determines its content. Fulfillment of this requirement depends on the personal qualities of the principal of the educational institution, on his/her understanding of the need to delegate responsibilities, as well as on the level of subordinates' professionalism. To ensure that delegation does not lead to misunderstandings, the following rules should be used: record all instructions, deadlines and wishes in writing; describe the task and the desired result in as much detail as possible; do not interfere in the process of work performance; be open to discussions and questions; be sure to analyze the work done and provide feedback; do not redo for others (for example, the report), explain mistakes and give time for correction [12, p.310].

The Google Meet service - a tool for video conferencing, webinars, distance learning, online presentations and consultations - is indispensable for effective feedback.

Public relations (PR activities) technologies are widely used in modern education. Their goal is to create a positive image of the educational institution. The essence of the use of this technology in education is that even the smallest positive moments, even insignificant achievements of students should be noted and brought to the attention of the public. One can quickly distribute information with cloud technologies, using the following services: Google Sites, YouTube, Blogger. Properly conducted work with the public (popularization of the institution, dissemination of information about events that took place - conferences, trainings, workshops, competitions, Olympiads, various leisure events, etc.) attracts children and their parents, gives advantages in the market of educational services and strengthens the position of the school among competitors.

After analyzing Google's cloud services, we can determine their main characteristics: free, easy access (universal account that provides access to the entire package of services), cross-platform (usability on different platforms), ease of use, intuitive interface, necessary functionality, anti-crisis [6, p.109].

Today, Google is the most convenient cloud tool for effective management in an educational institution. Using it in practice will ensure the reliability and convenience of the teaching staff. Its value would increase dramatically if it were not only used in individual educational institutions, but became a cross-cutting tool of the entire educational sector. The cloud environment becomes an environment for effective exchange of experience among teachers, and also allows the management of the institution to quickly make the necessary adjustments to the management process, coordinate and synchronize the actions of the teaching staff. Under the conditions of quarantine restrictions, there are unique opportunities to realize the potential of cloud technologies. 
Thus, the main advantages in the implementation of cloud technologies in terms of management process and administrative activities of the principal of the educational institution are:

- raising awareness of all participants in the educational process;

- involvement of teachers in the organization of the educational process and management of the educational institution;

- the possibility to focus on strategic objectives, transferring routine tasks to a lower level of management or automating them;

- access to data anywhere and anytime from different devices and in the absence of a specific stationary workplace;

- ensuring data protection against losses and openness of the educational environment (control, monitoring, evaluation, testing, questionnaires, etc. online);

- reduction of costs for maintenance of computer equipment, purchase of software and its systematic updating compared to traditional information and communication technologies [2, p. 252];

- improved and more effective management support of teachers, as well as strengthening control over the implementation and updating of documentation through automation and unification of reporting.

Having analyzed cloud technologies, we have identified their powerful capabilities in pedagogical management. Accordingly, we were interested in the real state of awareness and use of these technologies in management. To implement this task, we chose a method of questionnaires, which involved 136 principals of general secondary education institutions from two regions of Ukraine: Transcarpathian and Kharkiv. The survey was conducted before COVID-19 quarantine (November 2019), during the full lockdown (April 2020) and during the adaptive quarantine (September 2020).

The survey revealed that school principals:

- are aware of the concepts "cloud technologies", "cloud services", and use them in management;

- are motivated to deepen knowledge and develop skills of using cloud services in pedagogical management.

As a result of the diagnostics, we have identified three levels of digital competence of the principals of the educational institutions in the context of the implementation of cloud technologies in pedagogical management:

- harmonious - the principal is clearly aware of the progressiveness of cloud technologies as a means of effective management of educational activities; classifies cloud technologies as a crisis management group (the possibility of their use in a crisis period, for example, under quarantine conditions); is sure that the use of cloud services will positively affect the quality of work, will improve communication processes and, accordingly, feedback with colleagues, increase the level of competitiveness of their institution; allows remote management, delegation of authority; demonstrates willingness to use cloud technology in professional activities; knows the essence, advantages and disadvantages, functional features and capabilities, ways to use cloud technologies in the management of the educational process; is able to select services in accordance with the professional situation, to carry out managerial functions and solve professional problems using Google's XC; is motivated and capable of self-reflection; is ready to expand his/her knowledge, skills and abilities to implement the cloud environment, to spread his/her experience.

- functional - the principal understands that the use of cloud technologies provides certain advantages in the management of the educational process; is aware that their application can to some extent have a positive impact on the quality of management of the educational process; demonstrates interest in cloud services; knows some advantages and 
disadvantages, functional features and capabilities, ways to use Google $\mathrm{XC}$ in the management of the educational process of the educational institution; is able to use some services to solve certain professional situations; is able to self-reflect on his/her own level of mastery of Google's XC, shows some interest in deepening personal knowledge and skills in using cloud services; is ready to discuss the possibilities of using cloud technologies in professional activities with colleagues.

- unproductive - the principal is not aware of or neglects the benefits of using cloud technologies as a means of supporting the management of the educational process; is not aware of the progressiveness of cloud technologies or denies that their use can positively affect the quality of management of the educational process; does not want to use them in professional activities; is unaware of the nature, advantages and disadvantages, functional features and possibilities, ways to use Google $\mathrm{XC}$ in the management of the educational process; unable to use Google $\mathrm{XC}$ for effective professional tasks, management functions; unmotivated and incapable of self-reflection; is not interested in improving the level of his/her own information and digital competence in the aspect of using cloud technologies; does not want to discuss the possibility of their use in professional activities with colleagues [13].

After studying the online questionnaires (questions of theoretical, analytical and practical nature; open and closed forms), and grouping the answers of the respondents, we found that the results before, during the full lockdown and adaptive quarantine are very different.

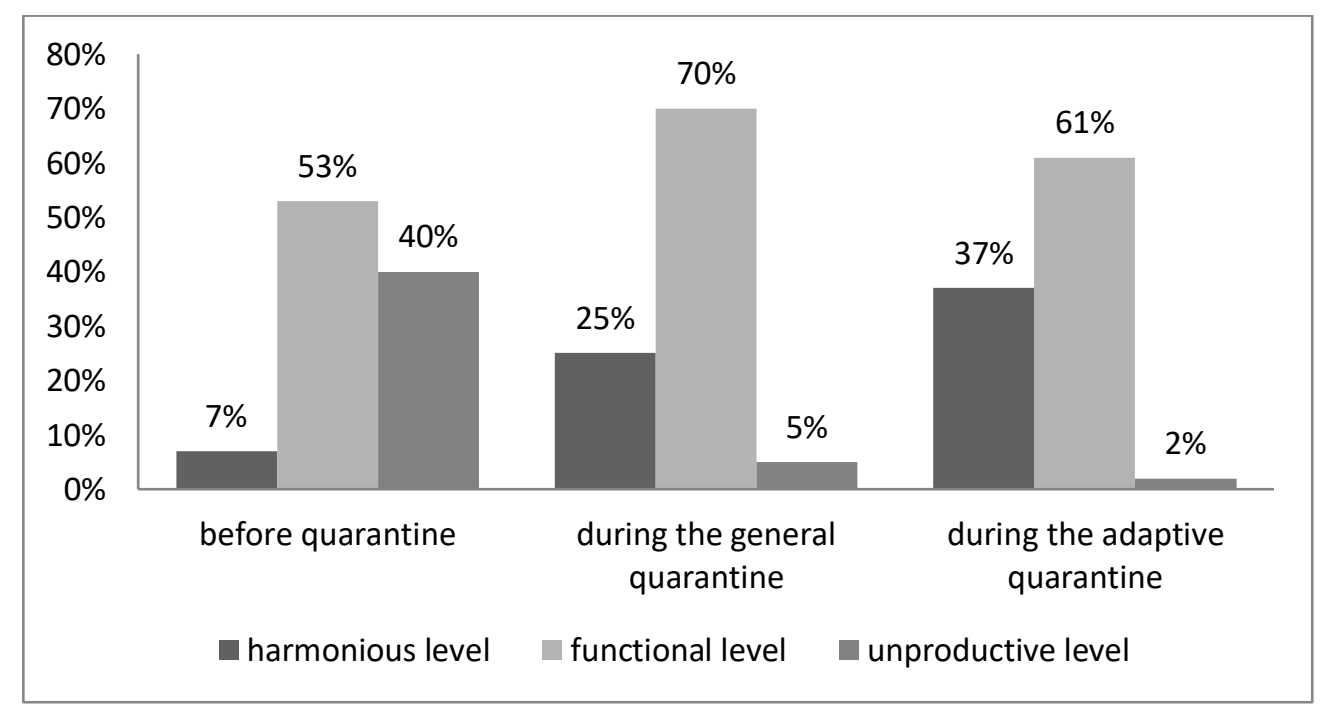

Figure 1. The level of information and digital competence of the principals of educational institutions in the context of cloud technologies implementation

The harmonious level of information and digital competence before the quarantine was found in $7 \%$ of managers, during the full lockdown - $25 \%$, during the adaptive quarantine $37 \%$; functional, respectively, $53 \%, 70 \%$ and $61 \%$; unproductive $40 \%, 5 \%$ and $2 \%$. That is, we see significant progress in a short period of time. Under the conditions of quarantine restrictions, the principals of educational institutions understood the need to use cloud services, became more flexible, as a result, their level of awareness, motivation, communication and practical skills have significantly increased.

Comparing the three stages of the online survey, we can conclude that the principals of educational institutions have realized that cloud technology is not something distant, burdensome and expensive, but rather something that allows minimizing the effects of lockdown quite quickly and efficiently. Accordingly, the principals see the main task of 
educational institutions in today's conditions in the transition to a qualitatively new level of building interpersonal interaction between participants in the educational process.

As a result of the diagnosis, it was found that the most popular among managers are the following services: Google Gmail, Google Forms, Google Drive. During the quarantine period, executives began to actively use Google Meet for video conferencing. Only $25 \%$ of the respondents use the function of collaborative and remote work on one document.

It is gratifying that the respondents expressed readiness to further increase their own level of information and digital competence. Accordingly, 98\% answered that they are ready to further increase the level of competence in the use of cloud technologies in educational management. Given the high demand, we have developed a 30-hour course for principals of educational institutions entitled "Effective use of cloud technologies in educational management".

\section{CONCLUSIONS AND PROSPECTS OF FURTHER RESEARCH}

Cloud technology, due to its powerful capabilities, is the headliner of the IT market today. The use of cloud technologies in pedagogical management involves scientifically sound actions of management and teachers, which are aimed at the rational use of time, physical and economic resources of all participants of the educational process.

The global pandemic made cloud technologies the basis for modernizing educational infrastructure in the future. During the quarantine period there has been a mass training of management and teaching staff. They got acquainted and learned to work with a large number of cloud services. And this, in turn, will change Ukrainian education in the future, because the leaders will use the mastered means in their daily work.

Today, cloud technologies are a full-fledged tool that allows institutions to create their own virtual space and effectively shape the educational online environment. The use of cloud technologies makes it possible to fully implement the main functions and areas of pedagogical management (forecasting and planning, management decision-making, organization of the implementation of decisions and plans, coordination and regulation of the activities of performers, ensuring operational, current and final control, accounting of the results of activities, analysis and evaluation of its effectiveness).

It has been revealed that numerous educational and managerial processes are effectively implemented in the cloud environment, namely: digitalization, feedback, collaboration, delegation, crowdsourcing, strategic planning (foresight), educational benchmarking, joint design, management of professional development of teachers, PR-activity of educational institution. control, monitoring, evaluation, testing, questionnaires online, etc.

To find out the real state of awareness and use of cloud technologies in pedagogical management, we conducted a diagnostic study among the principals of general secondary education institutions in two regions of Ukraine. The study showed that during the quarantine period there has been significant progress in awareness and motivation of managers regarding the appropriate and effective use of cloud technology in pedagogical management.

The study does not cover all aspects of the problems associated with the use of cloud technologies in pedagogical management. Further research should focus on using Google's capabilities to implement effective time management.

\section{REFERENCES (TRANSLATED AND TRANSLITERATED)}

[1] I. Arpaci, «Antecedents and consequences of cloud computing adoption in education to achieve knowledge management», Computers in Human Behavior, no. 70, 2017, pp. 382-390. (in English) 
[2] S.H. Lytvynova, «Theoretical and methodological foundations of designing a cloud-based learning environment of a secondary school», dis. PhD, Institute of Information Technologies and Teaching Aids, Kyiv, Ukraine, 2016. (in Ukrainian)

[3] M. M. Alabbadi, «Cloud computing for education and learning: education and learning as a service (ELaaS)», in 14th International Conference on Interactive Collaborative Learning, Riyadh, Saudi Arabia, 2011 , $\mathrm{pp}$ 589-594.

Available: https://citeseerx.ist.psu.edu/viewdoc/download?doi=10.1.1.458.3925\&rep=rep1\&type=pdf. Accessed on: Nov. 14, 2019. (in English)

[4] A. N. Tashkandi «Cloud computing adoption by higher education institutions in Saudi Arabia: an exploratory study». Cluster Computing, no. 18, 2015. pp. 1527-1537. [Online]. Available: https://link.springer.com/article/10.1007/s10586-015-0490-4. Accessed on: Nov. 14, 2019. (in English)

[5] S. Lohr, «Google and I.B.M. Join in "Cloud Computing" Research», New York [Online]. Available: http://www.nytimes.com/2007/10/08/technology/08cloud.html Accessed on: Nov. 23, 2019. (in English)

[6] V. O. Khrypun, «Google Cloud Services as a guide for preschool education management», dis. PhD, Institute of Information Technologies and Teaching Aids, Kyiv, Ukraine, 2019. (in Ukrainian)

[7] M. V. Noskova, «Internet-technologies in the activity of the head of a general educational institution: monograph». Lviv: Levada, 2017. (in Ukrainian)

[8] S. Odainyk, «The use of cloud technologies in the management of secondary schools», Nova pedahohichna dumka, no. 4, pp. 103-107, 2016. [Online]. Available: http://nbuv.gov.ua/UJRN/Npd_2016_4_27. Accessed on: Nov. 14, 2019. (in Ukrainian)

[9] S.G. Shmatko, D.V. Shlaev, and A.A. Sorokin, «Application of cloud technologies for effective management». IOP Conf. Series: Materials Science and Engineering, vol. 873, 2020. doi:10.1088/1757899X/873/1/012021. (in English)

[10] O. Alzakholi, L. Haji, H. Shukur, R. Zebari, S. Abas, and M. Sadeeq, "Comparison Among Cloud Technologies and Cloud Performance». JASTT, vol. 1, no. 2, pp. 40 - 47, 2020. doi:10.38094/jastt1219. (in English)

[11] V. Hladkova, A. Panchenko, and H. Panchenko, «Using Google services in the management of secondary education», Vidkryte osvitnie e-seredovyshche suchasnoho universytetu, no. 3, pp. 337-344, 2017. (in Ukrainian)

[12] M. D. Vynohradskyi, and O. M. Shkanova, Organization of the manager's work. Kyiv, Ukraine, 2002. (in Ukrainian)

[13] Yu. Nosenko, and V. Bohdan «The Implementation of Cloud Services in Ukrainian Pre-School Educational Institution Management», in 13th Int. Conf. ICTERI, CEUR Workshop Proceedings, Kyiv, 2017, pp. 451-458. [Online]. Available: https://core.ac.uk/download/pdf/132488055.pdf. Accessed on: Nov. 10, 2019. (in English)

Text of the article was accepted by Editorial Team 08.05.2020

\title{
ЗАСТОСУВАННЯ ХМАРНИХ ТЕХНОЛОГІЙ У ПЕДАГОГІЧНОМУ МЕНЕДЖМЕНТІ
}

\section{Швардак Маріанна Василівна}

кандидат педагогічних наук, доцент, доцентка кафедри педагогіки дошкільної та початкової освіти Мукачівський державний університет, м. Мукачево, Україна

ORCID ID 0000-0002-9560-9008

mariannasvardak2@gmail.com

\begin{abstract}
Анотація. У статті розкрито сутність поняття «хмарні технології» в контексті педагогічного менеджменту. 3'ясовано, що хмарні технології $\epsilon$ актуальними в освіті, інтенсивно інтегруються в загальну середню освіту, стають основою формування інформаційноосвітнього простору закладу, є незамінними в період загальнонаціонального карантину. Розглядаючи хмарне середовище як середовище ефективного педагогічного менеджменту, визначено принципи, на основі яких реалізуються хмарні технології управління закладом освіти. Виявлено, що використання хмарних технологій дає можливість керівнику закладу загальної середньої освіти повноцінно реалізувати основні функції та напрями педагогічного менеджменту. Окреслено основні сучасні процеси в хмарному середовищі (діджиталізація, фідбек, колаборація, делегування повноважень, краудсорсинг, стратегічне планування, освітній бенчмаркінг, спільне проєктування, управління професійним розвитком педагогів, PR-діяльність закладу освіти, контроль, моніторинг, оцінювання, тестування, анкетування в режимі «онлайн» тощо). Проаналізовано потужні можливості
\end{abstract}


системи хмарних сервісів Google в аспекті управління педагогічними працівниками та закладом освіти загалом.

Проведено діагностику на визначення стану і рівня обізнаності в можливостях реалізації ефективного педагогічного менеджменту через хмарні сервіси. До участі залучено директорів закладів загальної середньої освіти з двох областей України. Дослідження проводилось у три етапи: до введення карантину (листопад 2019 р.), у період загального карантину (квітень 2020 р.) та в період адаптивного карантину (вересень 2020). У результаті проведеної діагностики, нами визначено три рівні сформованості інформаційно-цифрової компетентності керівника закладу освіти в контексті реалізації хмарних технологій у педагогічному менеджменті: гармонійний, функціональний та непродуктивний. Виявлено, що в умовах карантинних обмежень освітні менеджери максимально акумулювали свої можливості, опанувавши за короткий проміжок часу необхідні хмарні сервіси, що зумовило різке підвищення рівня їх інформаційно-цифрової компетентності.

Ключові слова: хмарні технології; хмарні сервіси; педагогічний менеджмент; керівник; педагогічні працівники; заклад загальної середньої освіти.

\title{
ПРИМЕНЕНИЕ ОБЛАЧНЫХ ТЕХНОЛОГИЙ В ПЕДАГОГИЧЕСКОМ МЕНЕДЖМЕНТЕ
}

\author{
Швардак Марианна Васильевна \\ кандидат педагогических наук, доцент, \\ доцент кафедры педагогики дошкольного и начального образования \\ Мукачевский государственный университет, г. Мукачево, Украина \\ ORCID ID 0000-0002-9560-9008 \\ mariannasvardak2@gmail.com
}

\begin{abstract}
Аннотация. В статье раскрыта сущность понятия «облачные технологии» в контексте педагогического менеджмента. Выяснено, что облачные технологии интенсивно интегрируются в общее среднее образование, становятся основой формирования информационно-образовательного пространства учреждения, являются незаменимыми в период общенационального карантина. Рассматривая облачную среду как среду эффективного педагогического менеджмента, нами определены принципы, на основе которых реализуются облачные технологии управления учебным заведением. Выявлено, что использование облачных технологий дает возможность руководителю учреждения общего среднего образования полноценно реализовать основные функции и направления педагогического менеджмента. Определены основные современные процессы в облачной среде (диджитализация, фидбэк, коллаборация, делегирование полномочий, краудсорсинг, стратегическое планирование, образовательный бенчмаркинг, общее проектирование, управление профессиональным развитием педагогов, PR-деятельность учебного учреждения, контроль, мониторинг, оценка, тестирование, анкетирование в режиме «онлайн» и т.д.). Проанализированы мощные возможности системы облачных сервисов Google в аспекте управления педагогическими работниками и учебным учреждением в целом.

Проведена диагностика на определение состояния и уровня осведомленности в возможностях реализации эффективного педагогического менеджмента через облачные сервисы. К участию привлечены директора учреждений общего среднего образования из двух областей Украины. Исследование проводилось в три этапа: до введения карантина (ноябрь 2019), в период общего карантина (апрель 2020) и в период адаптивного карантина (сентябрь 2020). В результате проведенной диагностики нами определены три уровня сформированности информационноцифровой компетентности руководителя учреждения образования в контексте реализации облачных технологий в педагогическом менеджменте: гармоничный, функциональный и непродуктивный. Выявлено, что в условиях карантина образовательные менеджеры максимально аккумулировали свои возможности, овладев за короткий промежуток времени необходимимы облачными сервисами, что обусловило резкое повышение уровня их информационно-цифровой компетентности.
\end{abstract}

Ключевые слова: облачные технологии; облачные сервисы; педагогический менеджмент; руководитель; педагогические работники; учреждение общего среднего образования.

\section{$(\mathrm{Cc}) \mathrm{BY}-\mathrm{NC}-\mathrm{SA}$}

This work is licensed under Creative Commons Attribution-NonCommercial-ShareAlike 4.0 International License. 